\title{
TEMPERATURE AND HEAT FLOW WHEN TAPPING OF THE HARDENED STEEL USING DIFFERENT COOLING SYSTEMS
}

\section{TEMPERATURA Y FLUJO DE CALOR AL ROSCAR CON MACHOS ACERO ENDURECIDO UTILIZANDO DIVERSOS SISTEMAS DE LUBRICACIÓN}

\author{
Lincoln Cardoso Brandão ${ }^{1} \quad$ Reginaldo Teixeira Coelho ${ }^{2}$ \\ Recibido 9 de mayo de 2007, aceptado 04 de junio de 2009 \\ Received: May 9, 2007 Accepted: June 4, 2009
}

\begin{abstract}
RESUMEN
Trabajar los aceros endurecidos siempre ha sido un desafío para el corte de metales, particularmente en las operaciones de roscado. En el presente trabajo se mide la temperatura del acero AISI H13 endurecido, realizándose ensayos sin lubricación (seco) y dos sistemas con lubricación: aceite lubricante en grandes cantidades y mínima cantidad de líquido (minimum quantity of fluid MQF) a $20 \mathrm{ml} / \mathrm{h}$, en ambos casos se utilizó aceite integral mineral. El roscado se realiza sobre probetas de prueba de 100 x $40 \mathrm{~mm}$ con $14 \mathrm{~mm}$ de espesor y dureza de $55 \mathrm{HRc}$. Para medir la temperatura se utiliza la técnica de termocuplas situadas muy próximas al diámetro mayor del hilo de rosca (a 0.1, 2.5 y $5 \mathrm{~mm}$ de distancia). Se utilizan tres termocuplas a lo largo del espesor de la probeta de prueba a 3.0, 7.0 y $11.0 \mathrm{~mm}$ desde la entrada del roscado. Se hacen dos réplicas del registro de la temperatura para cada condición de corte ensayada. Se utiliza un modelo teórico-analítico de conducción de calor para evaluar la temperatura en la interfase de la probeta de prueba, determinar el flujo de calor y el coeficiente de convección. El menor incremento de la temperatura y del calor se observa al utilizar el método lubricante en grandes cantidades, seguido por el de MQF, al comparar con la condición en seco. El efecto es directamente proporcional a la cantidad de lubricante aplicado, siendo también significativo con el sistema MQF al compararlo con el corte en seco.
\end{abstract}

Palabras clave: Roscado, conducción del calor, cantidad mínima del líquido (MQL), acero AISI H13, temperatura.

\begin{abstract}
Machining hardened steels has always been a great challenge in metal cutting, particularly for tapping operations. In the present paper, temperature was assessed when tapping hardened AISI H13. Dry machining and two cooling/lubrication systems were used: flooded and minimum quantity of fluid $(M Q F)$ with 20ml/h, both using mineral oil. The tapping operation was performed on $100 \times 40 \mathrm{~mm}, 14 \mathrm{~mm}$ thick workpieces with $55 \mathrm{HRc}$. An implanted thermocouple technique was used for temperature measurement at distances very close to the highest thread diameter (at 0.1, 2.5 and $5.0 \mathrm{~mm}$ ). Three thermocouples were used for each distance along the workpiece diameter at 3.0, 7.0 and $11.0 \mathrm{~mm}$ from the tap entrance. Measurements were replicated twice for each condition tested. An analytical theoretical heat conduction model was used to evaluate the temperature at the tool-workpiece interface and determine the heat flow and convection coefficient. The smallest temperature increase and heat flow were observed when using the flooded system, followed by the MQF, compared to the dry condition. The effect was directly proportional to the amount of lubricant applied, as well as with the MQF system, when compared to dry cutting.
\end{abstract}

Keywords: Tapping, heat flow, minimum quantity of fluid (MQF), steel AISI H13, temperature.

\section{INTRODUCTION}

At the beginning of the 20th century, when F. W. Taylor used water for the first time to cool cutting operations, a significant increase on tool life was experienced. From that time, a large variety of cutting fluids have been used for this purpose [1]. Oil-based fluids can be emulsified in water (containing 1 to $20 \%$ of oil) or used pure, without any water addition. Using pure oil, mainly because of their lubricating properties, has been a very common

\footnotetext{
1 Departamento de Engenharia Mecânica. Universidade Federal de São João del Rei. São João del Rei. Minas Gerais, Brasil. E-mail: lincoln@ ufsj.edu.br

2 Departamento de Engenharia de Produção. Universidade de São Paulo. São Carlos, São Paulo, Brasil. E-mail: rtcoelho@ sc.usp.br
} 
procedure. Pure oil better lubricates which drastically reduces the heat due to friction at interfaces and helps to produce a good surface finishing.

Additionally, cutting force is also reduced, leading to less power consumption for the whole cutting process.

This has also been one of the main reasons for the use of cutting fluids with lubricating capacity [3]. Extreme pressure additives can also be applied in order to reduce the possibilities of adhesion at tool-chip interface [2].

Forces and power consumption in low speed machining processes, such as drilling, broaching and tapping are the most influenced by the lubricating properties of the cutting fluid. In those processes the temperature at the chip formation zone is relatively low and lubricating properties become more significant. Low power consumption corresponds to a good lubrication fluid and it is usually the first choice in industry [3].

In contrast, high speed machining processes, such as turning and milling, produces high temperatures at chiptool interface, which makes the cooling properties more important for a cutting fluid. The safety of the machinist is another concern because long exposure to cutting fluids may be related to skin diseases, eye irritations, lung diseases, etc $[4,5,6]$.

In addition, the current labor and environmental laws require tight control of maintenance, disposal, and residues emission into the atmosphere of the fluids [7-10]. Therefore, minimizing the use of cutting fluid has become a very important issue for nowadays. Two techniques have been intensively tested: dry cutting, also known as ecological machining, and cutting with a minimum quantity of lubricant (MQL), where a very low amount of fluid is used [11].

The MQL name is given to the process of pulverizing a very small amount of oil (less than $30 \mathrm{ml} / \mathrm{h}$ ) in a flow of compressed air. Some good results, in terms of tool life, have been obtained with this technique. Braga, et. al. [12] used this technique on drilling Aluminum-Silicon alloy (323) with carbide drills, without coating. The authors concluded that MQL could reduce the temperature on the chip formation zone, maintaining it at levels low enough to avoid tool material deterioration.

Similarly to drilling, tapping often uses cutting fluids and it is believed to benefit the process in many ways, such as force and temperature reduction and also in improving thread quality [13]. Tapping is one the most difficult operation in metalworking industry and it is often performed at final stages of the operation sequences.

On average, the coefficient of friction for dry sliding between common tool-workpiece materials is about 4 times compared to when a good lubrication fluid is used. And there are only small differences between the frictions coefficients measured with different oil-based fluids. Therefore, the use of any oil-based cutting fluid significantly reduces tapping force [13].

In addition, the application system may significantly affect the temperature at the cutting zone. Tests to define the temperature values and of the heat flow in drilling and tapping processes have been carried out with several methodologies. The use of thermocouples is simple and has a good accuracy to define temperature and heat flow together with analytical mathematical models [14].

The purpose of the experiments carried out for the present work is to study the temperature of the workpiece close to the machined surface during tapping operations using two different systems for fluid application. The results were compared to the same operation at dry condition. A theoretical heat flow model was used to evaluate the heat energy $(\mathrm{Q})$ during the tests and the convection coefficient (h) for the three application systems.

\section{EXPERIMENTAL WORK}

\section{Temperature measurement}

The machining trials involved tapping process of an AISI H13 workpiece ( $100 \times 40 \mathrm{~mm}$ and $14 \mathrm{~mm}$ thick) with 50 HRC hardness and the average chemical composition: $0.40 \% \mathrm{C}, 0.95 \% \mathrm{Si}, 0.31 \% \mathrm{Mn}, 0.011 \% \mathrm{P}, 0.006 \% \mathrm{~S}, 5 \%$ $\mathrm{Cr}, 0.12 \% \mathrm{Ni}, 1.25 \% \mathrm{Mo}$ and $0.13 \% \mathrm{Cu}$. Taps were single coated (TiAlN - TINAL FUTURA ${ }^{\mathrm{TM}}$ ) with $1.5 \mathrm{~mm}$ pitch, straight flute, overall length $100 \mathrm{~m}$ and thread length of 24 $\mathrm{mm}$ with reinforced shank length according DIN 371.

A milling machining center ROMI model Discovery 560 with $7500 \mathrm{rpm}$ and $15 \mathrm{~kW}$ of spindle power was used. The experimental conditions, chosen according to manufacturer's recommendation, are shown in table 1. Figure 1 shows the schematic of thermocouples embedded with $0.1 \mathrm{~mm}$ distance from the highest thread diameter, designated as Pos1. 
Table 1. Experimental conditions chosen for the tapping experiments.

\begin{tabular}{|c|c|c|c|c|}
\hline $\begin{array}{c}\text { Tool } \\
\text { code }\end{array}$ & $\begin{array}{c}\text { Hole } \\
\text { diameter } \\
{[\mathrm{mm}]}\end{array}$ & $\begin{array}{c}\text { Cutting } \\
\text { speed } \\
{[\mathrm{m} / \mathrm{min}]}\end{array}$ & RPM & $\begin{array}{c}\text { Feed } \\
\text { rate } \\
{[\mathrm{mm} /} \\
\mathrm{min}]\end{array}$ \\
\hline $\begin{array}{c}\text { B1278TCN } \\
* \text { M10 }\end{array}$ & 8,6 & 3,0 & 95,49 & 143,23 \\
\hline
\end{tabular}

The same configuration was used for the distances of 2,5 and 5,0 mm, Pos 2 and Pos 3, respectively. Along the workpiece thermocouples were positioned at 3,0; 7,0 and $11,0 \mathrm{~mm}$ from the tap entrance, designated as $\mathrm{T} 0, \mathrm{~T} 1$ and $\mathrm{T} 2$, respectively. They were type " $\mathrm{T}$ " of Copper-Constantan with gauge AWG $30\left(0,051 \mathrm{~mm}^{2}\right)$ and temperature range among -18 to $205^{\circ} \mathrm{C}$. A thermostatic bath with ethilenoglicol was used to calibrate them within the range of 10 to $90^{\circ} \mathrm{C}$. Figure 2 shows the general configuration of holes on a workpiece, planned to maximize material usage.
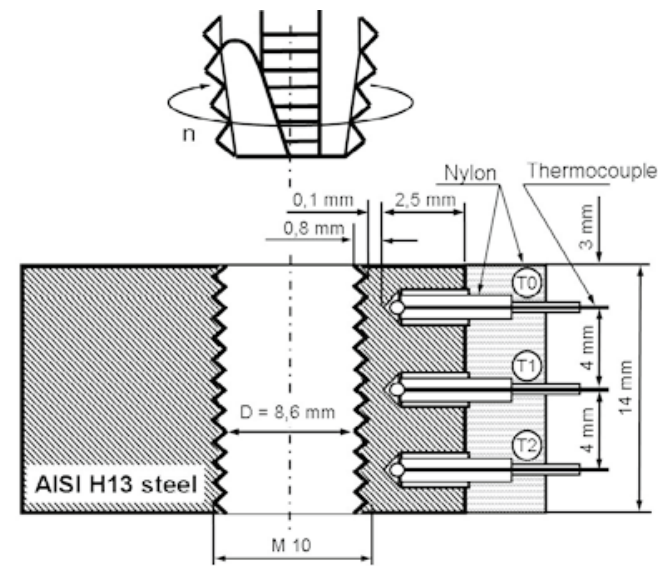

Figure 1. Lay-out of the embedded thermocouples. Example using Pos. 1 at $0,1 \mathrm{~mm}$ from the machined surface.

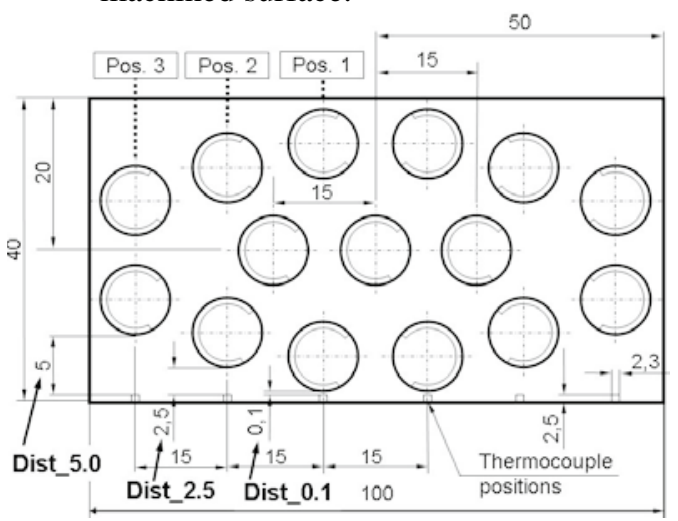

Figure 2. General configuration of holes on the workpiece.
The thermocouples were inserted in holes with $2,3 \mathrm{~mm}$ diameter. Tests were repeated twice for each condition. The thermocouples were short and connected to an electronic circuit, working as a signal conditioner, then to a National Instruments board model PCI-MI0-16E-4 to acquire the signals. The acquisition rate was $10 \mathrm{~Hz}$ for the temperature. The cutting fluid applied on both systems was BioG 850, a mineral-based oil, viscosity $18 \mathrm{cSt}$ at 40 ${ }^{\circ} \mathrm{C}$, produced by Microquímica ${ }^{\mathrm{TM}}$.

The MQL system used was the Accu-Lube Precision Applicator model 02A0-STD. The input pressure recommended by the supplier was between 550 and 1050 $\mathrm{kPa}$, and it was regulated in the tests at $590 \mathrm{kPa}$. The system was set for $20 \mathrm{ml} / \mathrm{h}$, both with integral mineral oil. Dry tests used the same machining conditions. Figure 3 shows the set up used for the experiments, and figure 4 shows a scheme diagram of the MQL system. In the figure 4 the word " $A$ " into the circle represents the line that came from the oil tank machine and the word "B" represents the compressed air line that came from the accumulator located in the laboratory.

The holes were initially drilled with single coated (TiAl) $\mathrm{N}$ tools model A3269TFL-8,6 and their diameter was kept within $8,6^{ \pm 0.02} \mathrm{~mm}$. Drilling conditions were $25 \mathrm{~m} / \mathrm{min}$ cutting speed and $27,76 \mathrm{~mm} / \mathrm{min}$ feed rate.

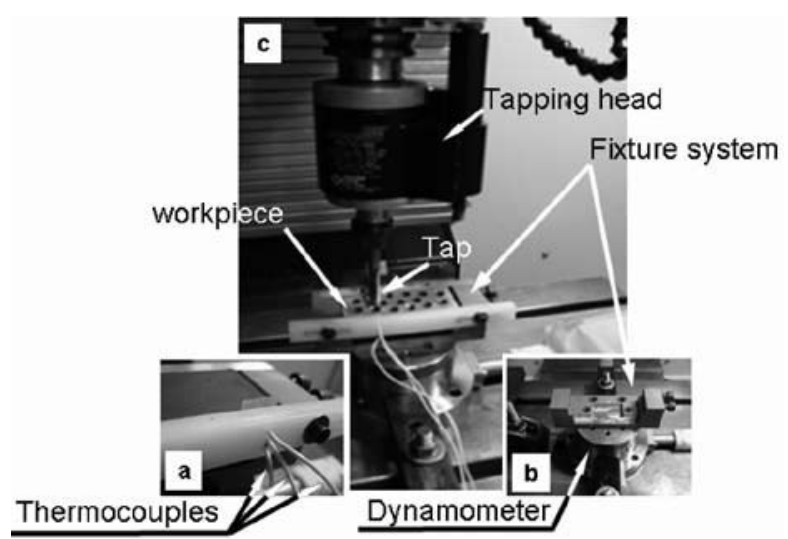

Figure 3. Lay-out of the experiment. 


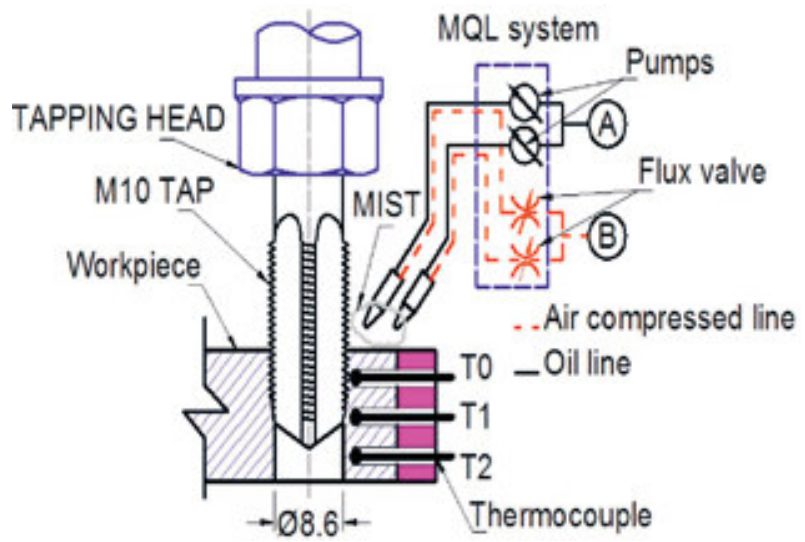

Figure 4. Scheme of the MQL system.

\section{Theoretical temperature evaluation}

To evaluate the temperature the one-dimensional moving heat source theory was adopted. The heat source moved inside a tube whose internal diameter is the hole and the outside diameter is the thread. Taking a small part of that imaginary tube, as illustrated in figure 5 , one can write down the energy balance according to Eq. (1):

$$
q_{x}+q_{x+d x}-q_{\text {conv }}=\Delta U
$$

Where:

$q_{x} \quad=$ input heat energy due to conduction [J];

$q_{c o n v} .=$ Output energy due to convection [J];

$\Delta U=$ Internal energy $[\mathrm{J}]$.

The heat source is the result of chip formation plus friction and the convection effect is the action of cooling system acting inside the hole, before and after the tap movement. There is heat flow in the radial direction, but because of the high tapping speed in the axial direction, that flow takes longer to spread and it will not be considered.

The energy parcels can be written as:

$$
q_{x}-\left(q_{x}+\frac{\partial q}{\partial x} d x\right)-q_{c o n v .}=d_{m} \cdot c p \cdot \frac{\partial T}{\partial t}
$$

Where:

$d_{m}=$ Small amount of mass;

$c_{p}=$ specific heat of the material.

Using Fourier's law and Newton's one for cooling, Eq. (2) becomes:

$-\frac{\partial}{\partial x}\left(-k \cdot A_{C} \frac{\partial T}{\partial x}\right) d x-h \cdot d A \cdot\left(T-T_{\infty}\right)=d m \cdot c_{P} \cdot \frac{\partial T}{\partial t}$

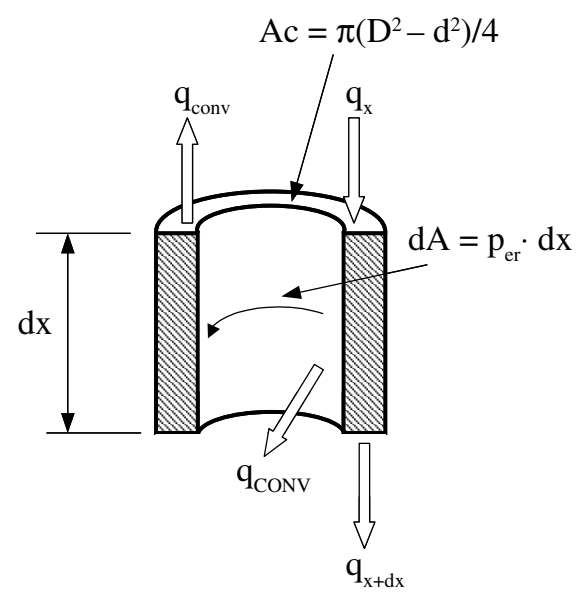

Figure 5. Scheme of system.

Assuming that $k$, the heat conductivity, and $A_{c}$, tube area, are constants in $x, h$ is the convection coefficient, and also that:

$$
\left(T-T_{\infty}\right)=\theta
$$

Equation (3) becomes:

$$
k \cdot A_{C} \frac{\partial^{2} \theta}{\partial x^{2}}-h \cdot d A \cdot \theta=d m \cdot c_{P} \cdot \frac{\partial \theta}{\partial t}
$$

But

$$
d A=p_{e r} d x \text { and } d m=A_{C} \cdot d x \cdot \rho
$$

where:

$p_{e \mathrm{r}}=$ perimeter of the convection area

$\rho=$ material's density

Inserting Equations (6) into Equation (5) and after some re-arrangements:

$$
\alpha \frac{\partial^{2} \theta}{\partial t^{2}}-v \theta=\frac{\partial \theta}{\partial t}
$$

where:

$$
\alpha=\frac{k}{\rho c_{p}}
$$

and;

$$
v=\frac{h \cdot p_{e r}}{A_{C} \cdot \rho \cdot c_{p}}
$$

Where: " $\alpha$ " is the diffusivity of the material and " $v$ " is a constant which depends on density " $\rho$ ", specific heat 
of material " $c_{p}$ ", perimeter " $p_{e r}$ " and the tube area " $A_{c}$ ". To solve the differential equation (7), Carslaw [14] first suggested using a general solution like equation (10):

$$
\theta=\mu \cdot e^{-v \cdot t}
$$

After inserting Equation (10) into (7) it results in:

$$
\alpha \frac{\partial^{2} \mu}{\partial x^{2}}=\frac{\partial \mu}{\partial t}
$$

Where the solution proposed by the author is presented in equation (12)

$$
\mu=\frac{q}{2 \cdot A_{C} \cdot \rho \cdot c_{p} \cdot(\pi \cdot \alpha \cdot t)^{\frac{1}{2}}} \exp ^{-\frac{\left(x-x^{\prime}\right)^{2}}{4 \cdot \alpha \cdot t}} 12
$$

where $x^{\prime}$ is the origin of the coordinate system. Therefore:

$$
\theta=\frac{q}{2 \cdot A_{C} \cdot \rho \cdot c_{p} \cdot(\pi \cdot \alpha \cdot t)^{\frac{1}{2}}} \exp ^{-v \cdot t-\frac{\left(x-x^{\prime}\right)^{2}}{4 \cdot \alpha \cdot t}}
$$

But the heat source is moving in relation to the coordenate system, with speed $v$. Then:

$$
x^{\prime}=v \cdot t
$$

Finally:

$$
\theta=\frac{q}{2 \cdot A_{C} \cdot \rho \cdot c_{p} \cdot(\pi \cdot \alpha \cdot t)^{\frac{1}{2}}} \exp ^{-v \cdot t-\frac{(x-v \cdot t)^{2}}{4 \cdot \alpha \cdot t}}
$$

Equation (15) gives the temperature at a certain point, $x$, as a function of time, due to a moving heat source along the $x$ axis. If a thermocouple placed at $x$ and measures the temperature-time curve, adjusting it to Equation (15) for the best values of $q$ and $v$, one can evaluate the amount of heat absorbed by the workpiece and also the convection coefficient, using Equation (9). Such a coefficient can be associated with the efficiency of the cooling system to remove heat from the workpiece.

To adjust the Equation (15) into the experimental points the following squared error function was proposed for minimization:

$$
\varepsilon=\sum_{i=1}^{N}\left(\theta_{i}-\hat{\theta}_{i}\right)^{2}
$$

Where:

$\theta_{\mathrm{i}}=$ Theoretical temperature at time $\boldsymbol{i}$;

$\hat{\theta}_{i}=$ Experimental temperature at time $i$

$\boldsymbol{N}=$ Number of measured temperature points

The minimization procedure used a MatLAB ${ }^{\mathrm{TM}}$ program applied, separately, to the curves of temperature at positions T0, T1 and T2. Each of these curves was obtained as an average curve using those obtained at Dist_0.1, Dist_2.5 and Dist_5.0 and each of their replications. Such procedure led to a unique curve for each depth of tapping. Each curve fitting resulted in a pair of values, $q$ and $h$, which represent the energy absorbed and the convection coefficient, respectively.

The technique of Levenberg-Marquardt was used with adjustment of error of $1 \mathrm{e}^{-10}$ and number of iterations of 10,000. This technique consist in take the minor dates errors that provoke a difference between experimental and adjust methodology and thus define the correct value for heat flux and convection coefficient.

\section{RESULTS AND DISCUSSION}

\section{Temperature measurement}

Figures 6, 7 and 8 show typical graphs of temperature at different positions along tapping depth.

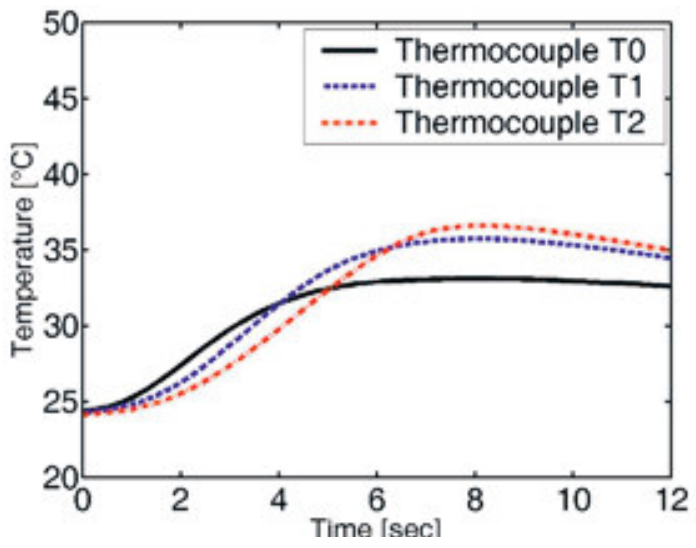

Figure 6. Temperature measured with flooded system. 


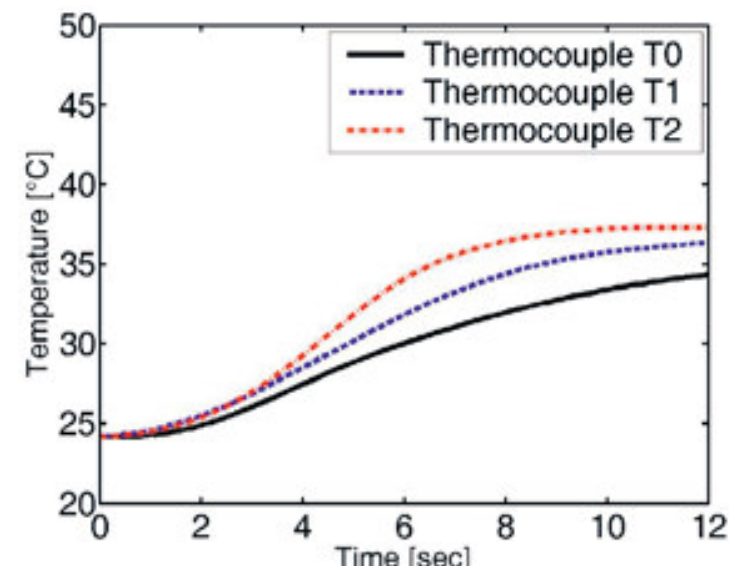

Figure 7. Temperature measured with MQL system.

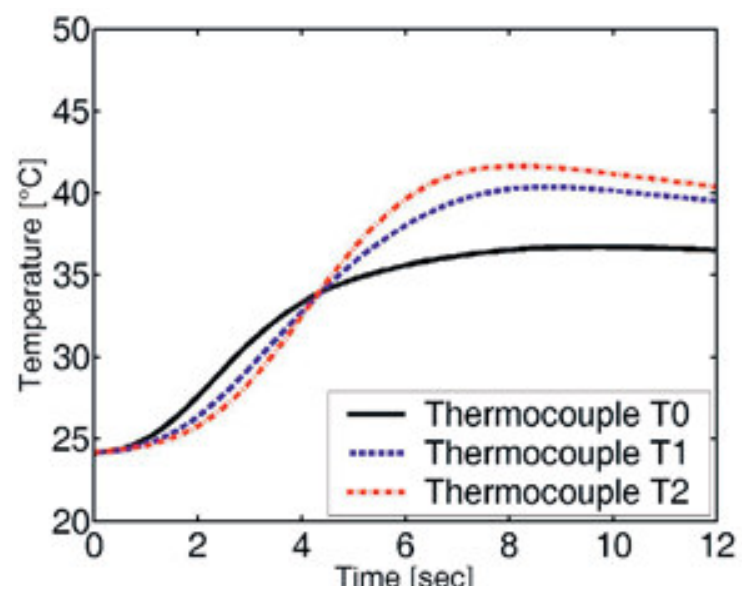

Figure 8. Temperature measured with dry condition.

The pattern of the temperature remained approximately the same for all cooling systems tested, and only the peak values varied. The tapping operation lasted about 12 seconds from touching the entrance to returning. The lowest peak of temperature always occurred at position $\mathrm{T} 0$, at $3.0 \mathrm{~mm}$ from the entrance. As the tap goes deeper, more heat is produced and accumulated at the chip formation front, followed by the friction between the newly formed thread and the tap edges after the chamfered part.

The thermocouples positioned ahead of the tool measured the heat wave, since feed speed was relatively low. As the chamfered front passes through the thermocouple position, the temperature tends to fall, because heat is lost through the workpiece and threaded surfaces, by conduction. After some time all the workpiece tends to the same temperature as before.

\section{ADJUSTING OF TEMPERATURE CURVES}

Figures 9,10 and 11 show examples of curves adjusted for different depths of threading using the flooded system, for example.

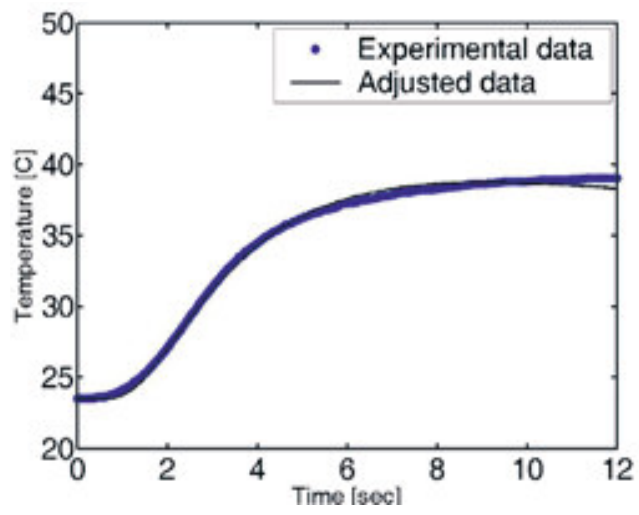

Figure 9. Curve fitting for thermocouple at T0 depth and flooded system.

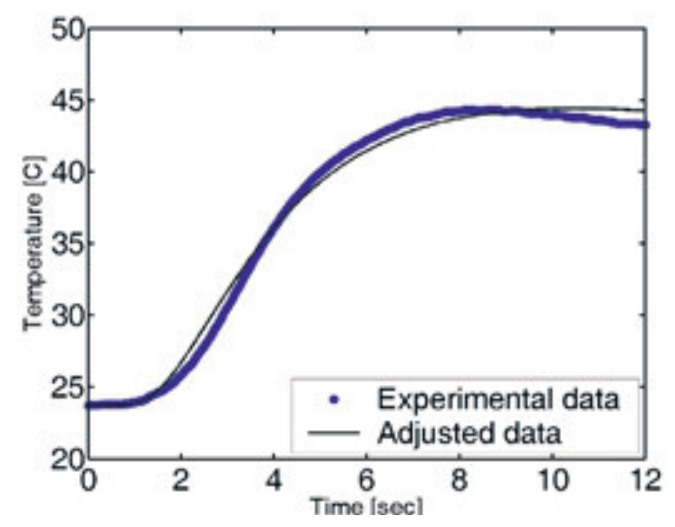

Figure 10. Curve fitting for thermocouple T1 and flooded system.

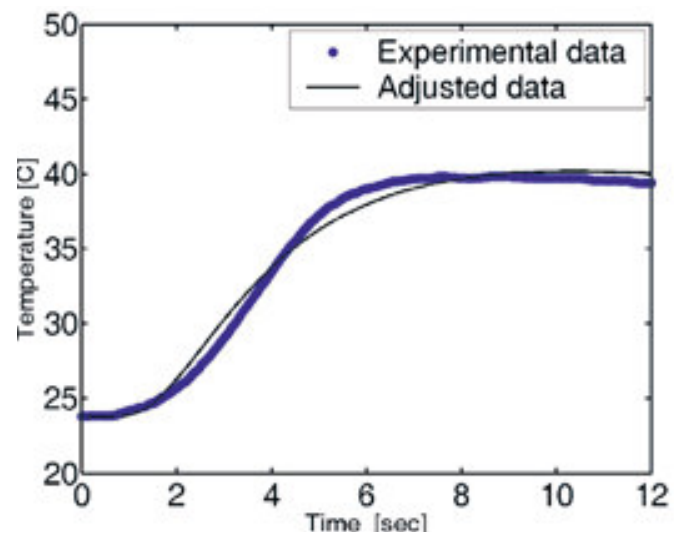

Figure 11. Curve fitted for thermocouple T2 and flooded system. 
Table 2. Values of heat flow and convection coefficient for all tests.

\begin{tabular}{|c|c|c|c|c|c|c|}
\hline \multirow{2}{*}{ Thermocouple } & \multicolumn{2}{|c|}{ Flooded } & \multicolumn{2}{|c|}{ MQL } & \multicolumn{2}{c|}{ Dry } \\
\cline { 2 - 7 } & $\begin{array}{c}\mathrm{Q} \\
{[\mathrm{W}]}\end{array}$ & $\begin{array}{c}\mathrm{h} \\
{\left[\mathrm{W} \cdot \mathrm{m}^{-2} \cdot \mathrm{C}^{-1}\right]}\end{array}$ & $\begin{array}{c}\mathrm{Q} \\
{[\mathrm{W}]}\end{array}$ & $\begin{array}{c}\mathrm{h} \\
{\left[\mathrm{W} \cdot \mathrm{m}^{-2} \cdot \mathrm{C}^{-1}\right]}\end{array}$ & $\begin{array}{c}\mathrm{Q} \\
{[\mathrm{W}]}\end{array}$ & $\begin{array}{c}\mathrm{h} \\
{\left[\mathrm{W} \cdot \mathrm{m}^{-2} \cdot \mathrm{C}^{-1}\right]}\end{array}$ \\
\hline $\mathrm{T} 0$ & 48.3 & 40.0 & 73.4 & 59.0 & 72.8 & 43.0 \\
\hline $\mathrm{T} 1$ & 67.3 & 45.0 & 86.0 & 6.0 & 102.1 & 47.0 \\
\hline $\mathrm{T} 2$ & 77.4 & 50.0 & 9.4 & 5.0 & 112.1 & 50.0 \\
\hline $\mathrm{V}_{\text {medium }}$ & 64.3 & 45.0 & 56.3 & 23.0 & 95.7 & 47.0 \\
\hline
\end{tabular}

It can be observed in figure 9 that adjustments of the experimental temperature and the theoretical temperature for the first thermocouple were almost perfect. Figure 10, however, shows that the adjustment for the thermocouple at $7.0 \mathrm{~mm}$ depth was still acceptable. For the thermocouple at $11.0 \mathrm{~mm}$ the adjustment was still acceptable, but worst of all. Experimental data shows a tendency to fall after the peak.

The theoretical curve can also reproduce that fall, although slower than the experimental data, mainly for the last thermocouples. It indicates heat is lost faster at the bottom of the workpiece than the theoretical equation is capable of modelling. There could be some inaccuracy with the value of $\alpha$, which was supposed to be $8.06 \mathrm{e}^{-6}$ in the present work. This was observed as a general pattern for all cooling systems.

Estimated values for energy and convection coefficients are shown in table 2. Comparing flooded and dry cutting, there is a general tendency of increasing the heat absorption and the convection coefficient. That happened because, as the heat source becomes deeper, the temperature increases and the heat wave go faster than the tool, reaching the thermocouple ahead.

That creates a higher temperature gradient, improving the heat absorption. Because of the gradient, the convection coefficient increases too. Concerning the average $h$ value, no significant difference was found between both systems. That could be expected since the heat lost by convection inside the hole and by both faces of the workpiece is very low, since the area is small, the gradient as well, and the time is short. Therefore, the curve adjustment can give an indication of what magnitude of convection coefficient can be expected in tapping.

When one looks at the data from MQL cooling system in table 2 , one sees a very distinct pattern. The compressed air flow to decrease the gradient between the surrounding air and the hole wall. It may also have created an air flow underneath the plate. On average, the heat absorption was lower with the flooded system, but the heat removal capacity, expressed by the convection coefficient, was the smallest of all, since the gradient was strongly reduced by the compressed air flow.

\section{CONCLUSIONS}

The fundamental aspects in temperature of the tapping process are investigated in this study. Experiments were carried out with overhead flood and minimum quantity of fluid, and compared with the dry tests.

Based on this study, the following points are summarized:

1. The objective was to obtain a temperature gradient. The obtained values show a small temperature variation among the closer positions of thermocouples and more distant in the tapping process.

2. In the positions 2 and 3 the temperature reduction happens based on the dissipation of the heat in the material of the workpiece due to performance of the cutting fluid.

3. The largest temperature reduction happened in the position 1 for the overhead flooding process.

4. The best adjustment occurred with the first thermocouple for all cooling systems and dry machining.

5. The medium value of heat flux for cooling systems, MQL and dry test was $64 \mathrm{~W}, 56 \mathrm{~W}$ and $95 \mathrm{~W}$, respectively.

6. The value of heat flux for coolant test show a tendency from the first to third assembly. Even so this tendency not was the same for dry and MQL where a randomization can be observed.

7. The values of convection coefficient they agree with the literature [14]. Even so wait for results that showing a decrease of these values from the dry test to flooded test. 


\section{ACKNOWLEDGMENTS}

We extend our sincere thanks to all who contributed to the present work, in particular to Titex-Prototype in Brazil (Eng. Marcos Soto Ice) and Frankfurt (Dr.Ing. Roland Heiler), Gerdau Açominas Brazil and also FAPESP - Brazil.

\section{REFERENCES}

[1] U. Heisel, M. Lutz, D. Spath, R. Wassmer e U. Walter. "A Técnica da Quantidade Mínima de Fluidos e sua Aplicação nos Processos de Corte". Revista Máquinas e Metais, Ed. Aranda. No 414, pp. 22-38. Fevereiro 1998.

[2] A.E. Diniz, F.C. Marcondes e N.L. Coppini. "Tecnologia da usinagem dos materiais". São Paulo; Ed. Artiliber, p. 242. 1999.

[3] W. Belluco and L. de Chiffre. "Testing of Vegetablebased cutting fluids by hole making operations". Lubrificating Engineering, pp. 12-16. January 2001.

[4] D. Sahm e T. Scheneider. "A produção sem refrigerante é interessante e deve ser mais conhecida". Revista Máquinas e Metais, Ed. Aranda No 367, pp. 38-55. Agosto 1996.

[5] M.A. El Baradie. "Cutting Fluids: Part II - Recycling and clean machining". Journal of Materials Processing Technology. Vol. 56 N $^{\circ} 1-4$, pp. 798806. January 1996.

[6] W.A. Burges. "Identificação de possíveis riscos à saúde do trabalhador". Ergo, p. 140-166. 1997.
[7] R.B. Aronson. "Why dry machining?" Manufacturing Engineering, p. 56-61. May 1995.

[8] F. Klocke and G. Eisenblätter. "Dry cutting". Annals of the CIRP. Vol. $46 \mathrm{~N}^{\circ}$ 2, pp.519-526. 1997.

[9] N. Narutaki, Y. Yamane, S. Tashima and H.A. Kuroki. "New advanced ceramic for dry machining". Annals of the CIRP. Vol. $46 \mathrm{~N}^{\circ} 1$, pp. 43-48. 1997.

[10] U. Heisel e M. Lutz. "Pesquisa de fluidos de refrigeração e de lubrificação". Revista Máquinas e Metais, Aranda Publisher. N ${ }^{\circ} 388$, pp. 40-49, mai 1998. (in portuguese).

[11] W.F. Sales, A.E. Diniz and A.R. Machado. "Application of cutting fluids in machining process". Journal of the Brazilian Society of Mechanical Sciences. Vol. $23 \mathrm{~N}^{\circ}$ 2. Rio de Janeiro, Brasil. 2001.

[12] D.U. Braga, A.E. Diniz, G.W.A Miranda and N.L. Coppini. "Minimum lubrification in Al-Si drilling". Journal of the Brazilian Society of Mechanical Sciences. Vol. $25 \mathrm{~N}^{\circ} 1$. Rio de Janeiro, Brasil. January-March 2003.

[13] T. Cao and J.W. Sutherland. "Investigation of thread tapping load characteristics through mechanics modeling and experimentation". International Journal of Machine Tools \& Manufacture. Vol. 42, pp. 1527-1538. 2002.

[14] H.S. Carslaw and J.C. Jaeger. "Conduction of Heat in Solids". Second edition. London. Oxford. 1957. 